\title{
On the trophic fate of Phaeocystis pouchetii (Hariot): IV. The formation of marine snow by $P$. pouchetii
}

\author{
Uta Passow ${ }^{1}$, Paul Wassmann ${ }^{2}$ \\ ${ }^{1}$ Marine Sciences Institute,University of California, Santa Barbara, California 93106, USA \\ ${ }^{2}$ Norwegian College of Fishery Science, University of Tromsø, N-9037 Tromse, Norway
}

\begin{abstract}
The formation of aggregates by Phaeocystis was investigated in coastal waters of northern Norway and in laboratory experiments. No evidence was found to support the hypothesis formulated by Wassmann et al. [(1990); Mar. Ecol. Prog. Ser. 66: 183-195] that Phaeocystis blooms are terminated by the formation of Phaeocystis aggregates from senescent colonies. Although Phaeocystis was observed to form aggregates in some instances, senescent colonies did not appear to have a higher sticking efficiency than growing ones. At senescence Phaeocystis colonies appeared to disintegrate. Further laboratory studies revealed that dissolved carbohydrates derived from the colonial matrix of Phaeocystis formed mucous particles which attached to siliceous fibers and glued them together. Detrital mucous flocs also formed from a natural particle assemblage and dissolved carbohydrates accumulated during the Phaeocystis bloom when rotated. We develop the hypothesis that cells and colonies of Phaeocystis may not contribute significantly to vertical flux, but that the sedimentation of mucous flocs presents a secondary pathway by which carbon assimilated during Phaeocystis blooms may sink to greater depth.
\end{abstract}

KEY WORDS: Aggregation Sedimentation Phaeocystis · Mucus

\section{INTRODUCTION}

The genus Phaeocystis with its global distribution has received increased attention during recent years. In the southern North Sea Phaeocystis blooms have occurred more frequently and intensively over the past decades. These blooms are considered a major nuisance since residuals clog fishing nets and cause the development of massive foam banks on beaches (Lancelot et al. 1987, Riegman et al. 1992). Phaeocystis may also be of importance in the carbon cycle at high latitudes, especially in the North Atlantic (Wassmann et al. 1990, Smith et al. 1991). A symposium dealing with the ecology of Phaeocystis-dominated systems held in Brussels in 1991, however, revealed significant lack of knowledge especially concerning the trophic fate of Phaeocystis blooms (Lancelot et al. 1992). As a consequence and continuation of ongoing research at the University of Tromsø, northern Norway (Huntley et al. 1987, Tande \& Båmstedt 1987, Hansen et al. 1990), the causes of the disappearance of Phaeocystis colonies were addressed during a workshop held in May 1992.

Although grazing may contribute to the disappearance of Phaeocystis blooms, it generally does not appear to be a major loss factor controlling bloom demise (Estep et al. 1990, Wassmann et al. 1990. Weisse et al. 1994). Disintegration appears to be of greater significance during the decline of many PhaeoCystis blooms (Veldhuis et al. 1986, Lancelot et al. 1987, Boekel et al. 1992). Whether or not sedimentation is a major loss process at the end of Phaeocystis blooms is controversial. Sedimentation rates were low in the Weddell Sea and in north Norwegian fjords (Bodungen et al. 1988, Lutter et al. 1989), but significant during a Phaeocystis bloom in the Barents Sea (Wassmann et al. 1990).

Sedimentation events terminating diatom blooms are generally preceded by aggregation of cells (e.g. Alldredge \& Gotschalk 1989), and Wassmann et al. (1990) raised the question whether Phaeocystis blooms 
may be terminated in a similar fashion. The present contribution reports on data collected during the workshop to test the hypothesis that senescent Phaeocystis colonies aggregate, assuming that aggregation is a prerequisite for their sedimentation. To address this question we studied (1) the abundance of marine snow in the field, (2) marine snow formation in the laboratory and (3) whether dissolved mucilage derived from Phaeocystis would deposit on particles and enhance the formation of mucous flocs. Data on the sedimentation of the Phaeocystis bloom will be presented in a second paper (U. Riebesell et al. unpubl.).

\section{MATERIAL AND METHODS}

Abundance of marine snow in the field. The abundance of marine snow was recorded within the upper $40 \mathrm{~m}$ in 2 fjords near Troms $\varnothing$, Balsfjord $\left(69^{\circ} 21^{\prime} \mathrm{N}\right.$, $\left.19^{\circ} 06^{\prime} \mathrm{E}\right)$ and Nordbotn $\left(69^{\circ} 40.5^{\prime} \mathrm{N}, 18^{\circ} 49^{\prime} \mathrm{E}\right)$ between May 10 and 30, 1992. Depth profiles of in situ abundance and size of marine snow (particles $>500 \mu \mathrm{m}$ ) were recorded with a remote-controlled still camera, modified from the design of Honjo et al. (1984). Particles within a small slab of light $(5 \mathrm{~cm})$ were eliminated, so that each frame represented a volume of $289 \mathrm{ml}$. Two to six frames from each depth (every 5 to $10 \mathrm{~m}$ ) were analyzed by image analysis. The equivalent spherical volume of particles was calculated from projected areas of particles.

Formation of Phaeocystis flocs in the laboratory. Seawater samples were collected from the in situ fluorescence maximum at the 2 stations to determine the aggregation potential of the plankton populations present, which were dominated by Phaeocystis. For comparison the aggregation potential was also determined of a population consisting of colonial Phaeocystis and Emiliana huxleyi derived from a mesocosm (volume $11 \mathrm{~m}^{3}$, with continuous daily $\mathrm{N}$ and $\mathrm{P}$ additions of 1.6 and $0.5 \mu \mathrm{M}$, respectively). Phaeocystis colonies used in the experiments had an average size of $650 \times 505 \mu \mathrm{m}$ and belonged to the species Phaeocystis pouchetii Hariot.

To determine the aggregation potential samples were rolled ( $2.8 \mathrm{rpm}$ ) in $285 \mathrm{ml}$ bottles (diameter $=6 \mathrm{~cm}$ ) on a rolling table (modified after Shanks \& Edmondson 1989) under simulated in situ conditions (temperature: $5^{\circ} \mathrm{C}$, light: $24 \mathrm{~h} 1 \mu \mathrm{E} \mathrm{m}^{-2} \mathrm{~s}^{-1}$ ). The time interval until flocs $>1 \mathrm{~mm}$ appeared was recorded. The aggregation potential is the inverse of this time interval and is a relative measure of the sticking efficiency of the enclosed populations. It is the product of the sticking coefficient of the particles and their collision rate. Assuming that the sinking velocity of colonies was the same in all samples (which is a reasonable assumption as the average sizes were similar) the differences in the aggregation potential between samples are due to differences in the concentration and sticking coefficients of colonies. To evaluate the impact of the concentration on the aggregation potential, relative differences in calculated flocculation half-times $\left(t_{1 / 2}\right)$ were compared assuming constant sticking coefficients. The half-time of flocculation (time interval after which half of all particles are aggregated) was calculated for each sample by

$$
t_{1 / 2}=\ln 2\left(\frac{2}{3} \alpha d^{3} N G\right)^{-1},
$$

where $N$ and $d$ are the concentrations and diameters $(500 \mu \mathrm{m})$ of colonies in the samples. The shear, $G$, was assumed to be $0.3 \mathrm{~s}^{-1}$ and the sticking coefficient $\alpha$ was arbitrarily set at 0.025 .

Formation of marine snow from mucilage. To investigate the formation of mucous flocs, mucilage was enriched in seawater from Balsfjord on May 18 (Expt 1) and from the mesocosm (Expt 2) in 2 steps. The samples were prefiltered through a GF/C and a membrane $0.2 \mu \mathrm{m}$ filter and enriched over 500 Dalton by amicon filtration under argon gas pressure. The fraction which had passed the 500 Dalton is called 'clean water' and the fraction which remained above 'mucilage'. The different fractions were combined with borosilicate fibers (Expt 1) representing non-living particles or the diatom Thalassiosira nordenskjoeldii (Expt 2) and rotated on the rolling table. The concentration of particulate and dissolved carbohydrates was recorded during the flocculation experiments to monitor a possible transfer of polysaccharides from the dissolved $(<0.4 \mu \mathrm{m})$ into the particulate pool. Particulate polysaccharides were furthermore stained with Alcian blue (aqueous solution of $0.02 \%$ in $0.06 \%$ acetic acid) and investigated microscopically. Measurements of the aggregation potential were made to indicate changes in flocculation behavior.

Similar experiments were conducted with material collected from unpoisoned sediment traps (cylindrical PVC traps, diameter $93 \mathrm{~mm}$, height/diameter $=6.2$, sampling interval 4 to $5 \mathrm{~d}$ ) positioned at $40 \mathrm{~m}, 60 \mathrm{~m}$ and $100 \mathrm{~m}$ in Balsfjord during 2 periods from May 18 to 27 . The unaltered material was diluted 1 to 5.7 and 1 to 3.3 , for the 2 periods respectively, and rolled on the rolling table. The formation of aggregates, stainable polysaccharide particles and changes in the particulate and dissolved carbohydrate pools were recorded.

The concentration of carbohydrates, both dissolved and particulate, was determined spectrophotometrically with the phenol-sulphuric acid reaction using glucose as a standard (Dubois et al. 1956, Strickland \& Parsons 1972). Particulate carbohydrates retained on a $0.45 \mu \mathrm{m}$ membrane filter were hydrolyzed for $20 \mathrm{~h}$ in $5 \mathrm{ml}$ of $80 \%$ sulfuric acid prior to analysis. Empty filters were used as blanks. 


\section{RESULTS AND DISCUSSION}

\section{Theoretical considerations}

The original hypothesis that colonies of Phaeocystis would have a high aggregation efficiency was based on 2 major arguments:

(1) Aggregation theory predicts that the aggregation rate depends on the collision rate of individual particles. The large potential size of Phaeocystis colonies (up to $5000 \mu \mathrm{m}$ in diameter) and the high concentration of colonies during blooms $\left(>10^{4} 1^{-1}\right)$ should ensure high collision rates.

(2) The aggregation rate furthermore depends on the percentage of collisions which result in attachment of the colliding particles, i.e. on the stickiness coefficient $\alpha$. The colony matrix of Phaeocystis consists of muco-polysaccharides (Lancelot 1983, Boekel 1992) which generally are very sticky and an important component of marine snow (Alldredge et al. 1993). Senescent colonies are often assumed to be especially sticky.

We furthermore tested the hypothesis that dissolved carbohydrates produced abundantly during Phaeocystis blooms contribute to the formation of mucous flocs. According to this hypothesis dissolved carbohydrates form mucous particles abiotically which deposit on other particles, binding them together.

\section{Phaeocystis flocs: abundance in the field}

The bloom in Balsfjord had passed its peak and was senescent (Riebesell et al. unpubl.), but abundance of colonial Phaeocystis still exceeded $10^{3}$ colonies $1^{-1}$ in the chlorophyll maximum. In Nordbotn Phaeocystis was still blooming and colonies appeared comparatively intact. Fig. 1 depicts concentrations of particles $>0.5 \mathrm{~mm}$ in Nordbotn and Balsfjord, as revealed by the marine snow camera. Particles in the size class $0.5-1.0 \mathrm{~mm}$ presumably reflected in part large, nonaggregated Phaeocystis colonies and were more abundant in Nordbotn (Fig. 1A) compared to Balsfjord (Fig. 1B). Concentrations of marine snow $>1 \mathrm{~mm}$ were also lower in Balsfjord than in Nordbotn (Fig. 1A, B). Similar observations were made by divers, who collected some aggregates consisting of Phaeocystis and debris in Nordbotn, but observed no aggregates in Balsfjord (Riebesell pers. comm.). To investigate whether the difference in the degree of flocculation was due to different levels of turbulent mixing as described for the North Sea (Riebesell 1993), we measured the aggregation potential of the different populations.

\section{Phaeocystis flocs: formation in the laboratory}

By comparing the aggregation potentials of the different populations, the relative capacities of the populations to form aggregates, independent of differences in the in situ mixing regimes, can be compared. The plankton population in Balsfjord had a relatively low aggregation potential (Table 1). This concurs with the respective in situ observations of low floc abundance. The aggregation potential was higher when the concentration of colonies was artificially enriched with hand-picked colonies. Hand-picking selected for intact, less fragile colonies of the same population. The aggregation potential of the population from Nordbotn was higher compared to Balsfjord, confirming in situ observations. Colonies from the mesocosm flocced rapidly (high aggregation potential), adhering directly to each other, and appeared to be very sticky, sticking to pipettes, etc.

Differences in the average sticking coefficients of colonies from the different experiments cannot be deduced directly from aggregation potentials given in Table 1 as those could also result from the differences in concentrations, i.e. collision frequencies. Assuming size, sinking velocity and stickiness of individual colonies to be the same in all experiments, the lower concentration of colonies in the non-concentrated Balsfjord water should result in an expected aggregation potential more than 2 times lower than for the enriched Balsfjord water, and 4 times lower than for the enriched population from the mesocosm. A comparison between the calculated aggregation potentials and the recorded ones, if both are normalized against the experiment with the highest aggregation potential (the enriched mesocosm population, $2 \mathrm{~B}$ ), shows that the

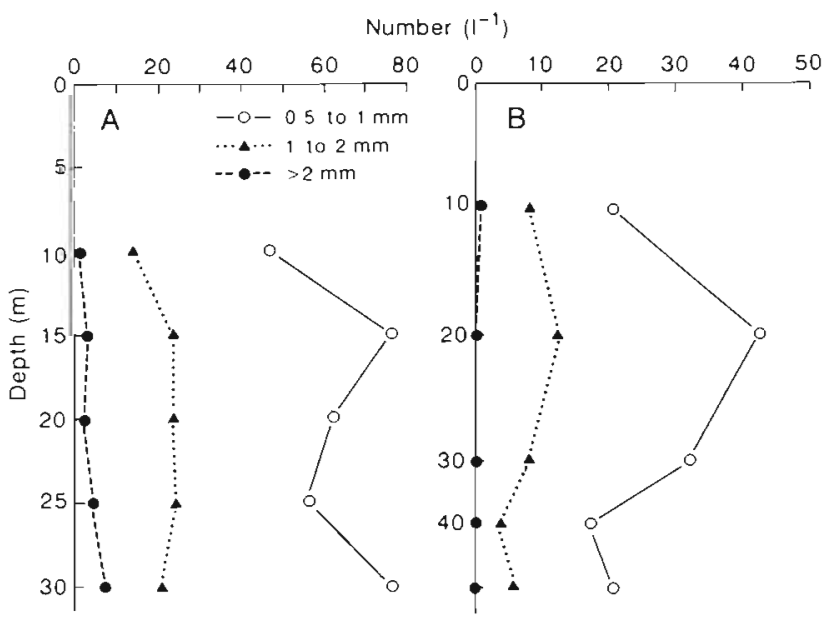

Fig. 1 Depth profiles of aggregates as revealed by remotecontrolled still camera in (A) Balsfjord (22 May 1992), and (B) Nordbotn (20 May 1992). Three size classes are indicated 
Table 1. Flocculation time (time to form flocs $>1 \mathrm{~mm}$ on a rolling table) and theoretical half times (calculated from Eq. 1 assuming stickiness to be the same for all colonies) of the different populations of Phaeocystis. The respective aggregation potentials (inverse of flocculation and half times) were normalized against the population with the highest aggregation potential, $2 \mathrm{~b}$. ND: not determined

\begin{tabular}{|c|c|c|c|c|c|}
\hline \multirow[t]{2}{*}{ Sampling site } & \multirow{2}{*}{$\begin{array}{l}\text { Description and } \\
\text { colony abundance }\end{array}$} & \multicolumn{2}{|c|}{ Recorded } & \multicolumn{2}{|c|}{ Expected } \\
\hline & & $\begin{array}{l}\text { Flocculation time } \\
\text { (h) }\end{array}$ & $\begin{array}{c}\text { Aggregation } \\
\text { potential } \\
\text { (normalized) }\end{array}$ & Half time & $\begin{array}{c}\text { Aggregation } \\
\text { potential } \\
\text { (normalized) }\end{array}$ \\
\hline 1a. Balsfjord & $\begin{array}{c}\text { Senescent, } 4 \text { samples } \\
\text { between } 13 \text { and } 27 \text { May } \\
\quad\left(2.5 \times 10^{3} \mathrm{l}^{-1}\right)\end{array}$ & $>48$ & $\leq 0.3$ & 56 & 0.3 \\
\hline 1b. Balsfjord & $\begin{array}{l}\text { Enriched, with intact } \\
\text { colonies }\left(7 \times 10^{3} 1^{-1}\right)\end{array}$ & $24-36$ & $0.5-0.4$ & 20 & 0.7 \\
\hline 2a. Mesocosm & Healthy $\left(5 \times 10^{3} \mathrm{I}^{-1}\right)$ & $24-36$ & $0.5-0.4$ & 28 & 0.5 \\
\hline 2b. Mesocosm & $\begin{array}{l}\text { Enriched, with healthy } \\
\text { colonies }\left(10 \times 10^{3} \mathrm{l}^{-1}\right)\end{array}$ & $<12$ & $\geq 1$ & 14 & 1 \\
\hline 3. Nordbotn & Healthy & $24-36$ & $0.5-0.4$ & ND & ND \\
\hline
\end{tabular}

measured aggregation potentials tend to be similar or slightly lower than expected if stickiness were the same (Table 1). This suggests that the stickiness did not differ appreciably or was lower for senescent populations. Differences in measured aggregation potentials presumably resulted primarily from differences in the concentrations of colonies. Senescent colonies from Balsfjord often disintegrated during handling, and the flocculation of senescent colonies may have been indirectly inhibited by a high rate of colony breakage and dissolution.

Our measurements of aggregation potential indicate that colonies from senescent populations did not have a higher sticking coefficient than those from growing populations. This contrasts with results for many diatoms (Alldredge \& Gotschalk 1989, Kiørboe et al. 1991), but concurs with the findings of Riebesell (1993), who observed no change in stickiness with the physical state of Phaeocystis colonies. Although Phaeocystis colonies can at times form aggregates especially together with diatoms (as observed in this study in Nordbotn and by Riebesell 1993) no evidence was found that the disappearance of Phaeocystis blooms in north Norwegian fjords is the result of aggregation and subsequent sedimentation of colonies, as (1) in situ abundance of flocs was low, especially during senescence, (2) colonies and cells were rarely found in traps (Lutter et al. 1989, Riebesell et al. unpubl.), and (3) the population had a low aggregation potential in the laboratory.

Although no aggregation or sedimentation (U. Riebesell et al. unpubl.) of colonies and cells was recorded, our field and laboratory observations indicate that senescent colonies in Balsfjord nevertheless disappeared from the water column. Disappear- ance of Phaeocystis has been observed at Balsfjord before, and was attributed to herbivore grazing and/or degradation and remineralization (Lutter et al. 1989). Microscopical observations revealed that during our study colonies in Balsfjord disintegrated and that cells inside the colony matrix developed into flagellated cells leaving the mucus structure (Noji pers. comm.). Lysis of Phaeocystis has been observed by Boekel et al. (1992) in the southern North Sea. Disintegration and dissolution seems to be dependent on the firmness and morphology of the colony, being dependent on the composition of the mucus polymers (Boekel 1992). Although of obvious significance for the the fate of Phaeocystis blooms, disruption of colonies (Veldhuis et al. 1986) and disintegration and dissolution of the colony matrix after flagellated cells have left (Rousseau et al. 1994) is only briefly described.

Dissolution of the matrix of senescent colonies will contribute to the accumulation of mucilage during Phaeocystis blooms. Extremely high (up to $64 \%$ of assimilated carbon) extracellular release of mostly carbohydrates during nutrient shortage furthermore leads to the high concentrations of carbohydrates observed during blooms of Phaeocystis (Guillard \& Hellebust 1971, Lancelot 1983, Eberlein et al. 1985 , Fernandez et al. 1992, Thingstad \& Billen 1994). The carbohydrates, which accumulate during Phaeocystis blooms, seem to largely resist rapid microbial degradation (Eberlein et al. 1985, Thingstad \& Billen 1994). High concentrations of dissolved carbohydrates may lead to the formation of foam on the sea surface in high energy environments like the southern North Sea, but we propose that in less turbulent water it may also enhance formation of mucous flocs. 


\section{Formation of mucous flocs from mucilage}

The following experiments were conducted to test whether dissolved $(<0.4 \mu \mathrm{m})$ mucilage derived from Phaeocystis may deposit on particles and may act as a binding agent entraining other particles to form mucous flocs. The silicious fibers used as particles in Expt 1 represented non-living particles, whereas the diatom culture added in Expt 2 was expected to influence dynamics actively.

During Expt 1 stainable polysaccharide particles ( 5 to $50 \mu \mathrm{m}$ ) formed in treatments with mucilage, but not in treatments with clear water (Table 2A, Fig. 2). This suggests that polysaccharide particles were formed from the mucilage of Phaeocystis. The aggregation potential was appreciably higher in treatments with mucilage, indicating that the presence of particulate polysaccharides promoted the formation of large, macroscopically visible mucous flocs. The appearance of particulate polysaccharides was paralleled by a decrease of dissolved carbohydrates concentration (Table 2A), confirming that particulate polysaccharides formed from the pool of dissolved carbohydrates. The presence of fibres seemed to enhance this transfer of dissolved carbohydrates and polysaccharide particles deposited preferably onto fibers (Fig. 2).

In Expt 2 the diatom Thalassiosira nordenskjoeldii (in late exponential phase non-axenic) was added to the 'mucilage' and 'clean water' fractions (Table 2B). In the mucilage treatments dissolved carbohydrates decreased even more than during the first experiment but stainable polysaccharide particles above $5 \mu \mathrm{m}$ were scarce in treatments without $T$. nordenskjoeldii. Mucilage used in the second experiment was derived from healthier colonies and may have had different properties, explaining the absence of stainable polysaccharide particles formed from Phaeocystis mucilage. However, when fibers were added, in a later additional step (data not shown), bigger stainable polysaccharide particles attached to fibers similar as shown in Fig. 2. This suggests that the non-living fibers may have been more suitable to allow deposition of mucous material than the live cells of $T$. nordenskjoeldii which may have inhibited attachment and build-up of mucous particles. The excretion of substances inhibiting flocculation of cells has been shown for Skeletonema costatum (Kiørboe \& Hansen 1993).

Differences in the formation of polysaccharide particles were minor between treatments with 'mucilage' and those with 'clean water' during the second experiment. Thalassiosira nordenskjoeldii and bacteria present in the culture appear to have dominated aggregation processes during Expt 2, masking any influence of the Phaeocystis mucilage. $T$. nordenskjoeldii forms ubiquitous amounts of transparent exopolysaccharide particles and flocs easily when in stationary phase (U.P. pers. obs.). Polysaccharide particles formed in treatments with $T$. nordenskjoeldii cells differed from those of the Phaeocystis mucilage, were small and diffuse and did not appear to bind cells together. Large flocs consisting of cells, but very little mucus, formed in treatments with cells when rotated, but no flocs

Table 2. Formation of marine snow from mucous flocs. Flocculation time, formation of polysaccharide particles and changes in concentration of dissolved carbohydrates in mucilage enriched and clean water (see text for explanation) with and without the presence of other particles. Also shown are the initial concentrations of dissolved carbohydrates (DCarb.; glucose equivalents). Thal. Thalassiosira nordenskjoeldii; $\mathrm{Cl}$. water: clean water; $(-+)$ no discrete, but smaller diffuse particles; ND: not determined

\begin{tabular}{|c|c|c|c|c|}
\hline \multirow{2}{*}{$\begin{array}{l}\text { A: Expt } 1 \\
\text { Sample }\end{array}$} & \multirow[b]{2}{*}{$\begin{array}{l}\text { Initial } \\
\text { DCarb. } \\
\left(\mathrm{mg} \mathrm{l}^{-1}\right)\end{array}$} & & \multirow[b]{2}{*}{$\begin{array}{c}\text { After } 48 \text { h rotation } \\
\text { Stained particles } \\
\text { present }\end{array}$} & \multirow[b]{2}{*}{$\begin{array}{c}\text { DCarb. } \\
\% \text { decrease }\end{array}$} \\
\hline & & $\begin{array}{c}\text { Flocculation } \\
\text { time }(\mathrm{h})\end{array}$ & & \\
\hline Mucilage & 1.4 & $12-24$ & + & 29 \\
\hline Mucilage + fibers & 1.4 & $12-24$ & + & 43 \\
\hline Cl. water & 0.7 & $>48$ & - & ND \\
\hline Cl. water + fibers & 0.7 & $>48$ & - & ND \\
\hline \multicolumn{5}{|l|}{ B: Expt 2} \\
\hline Sample & $\begin{array}{l}\text { Initial } \\
\text { DCarb. } \\
\left(\mathrm{mg} \mathrm{l}^{-1}\right)\end{array}$ & $\begin{array}{c}\text { Flocculation } \\
\text { time }(\mathrm{h})\end{array}$ & $\begin{array}{c}\text { After } 18 \text { h rotation } \\
\text { Stained particles } \\
\text { present }\end{array}$ & $\begin{array}{l}\text { DCarb. } \\
\% \text { decrease }\end{array}$ \\
\hline Mucilage & 1.1 & $>18$ & - & 54 \\
\hline Mucilage + Thal. & 2.6 & $<12$ & $(-+)$ & 77 \\
\hline Control (non-rotated) & 2.6 & $>18$ & $(-+)$ & 77 \\
\hline Cl. water & 0.6 & $>18$ & - & 48 \\
\hline Cl. water + Thal. & 2.0 & $12-18$ & $(-+)$ & 81 \\
\hline Control (non-rotated) & 2.0 & $>18$ & $(-+)$ & 71 \\
\hline
\end{tabular}




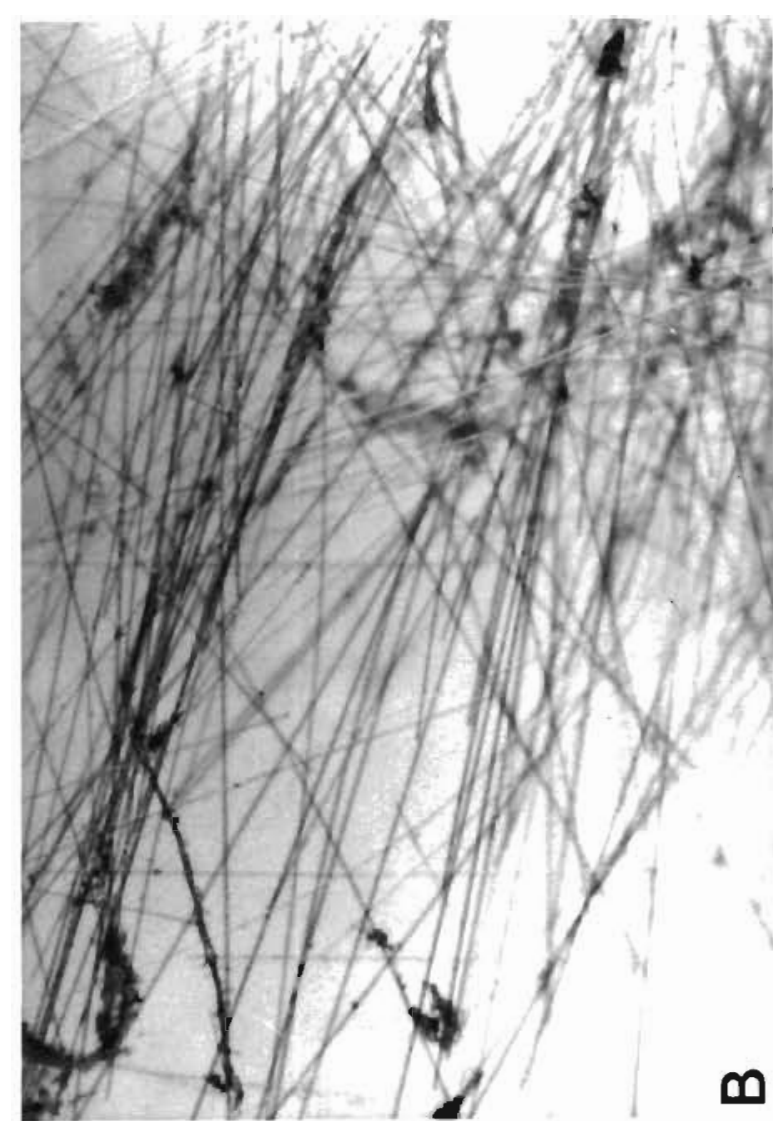

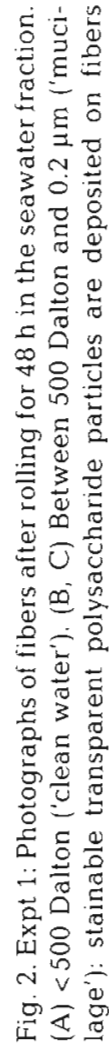
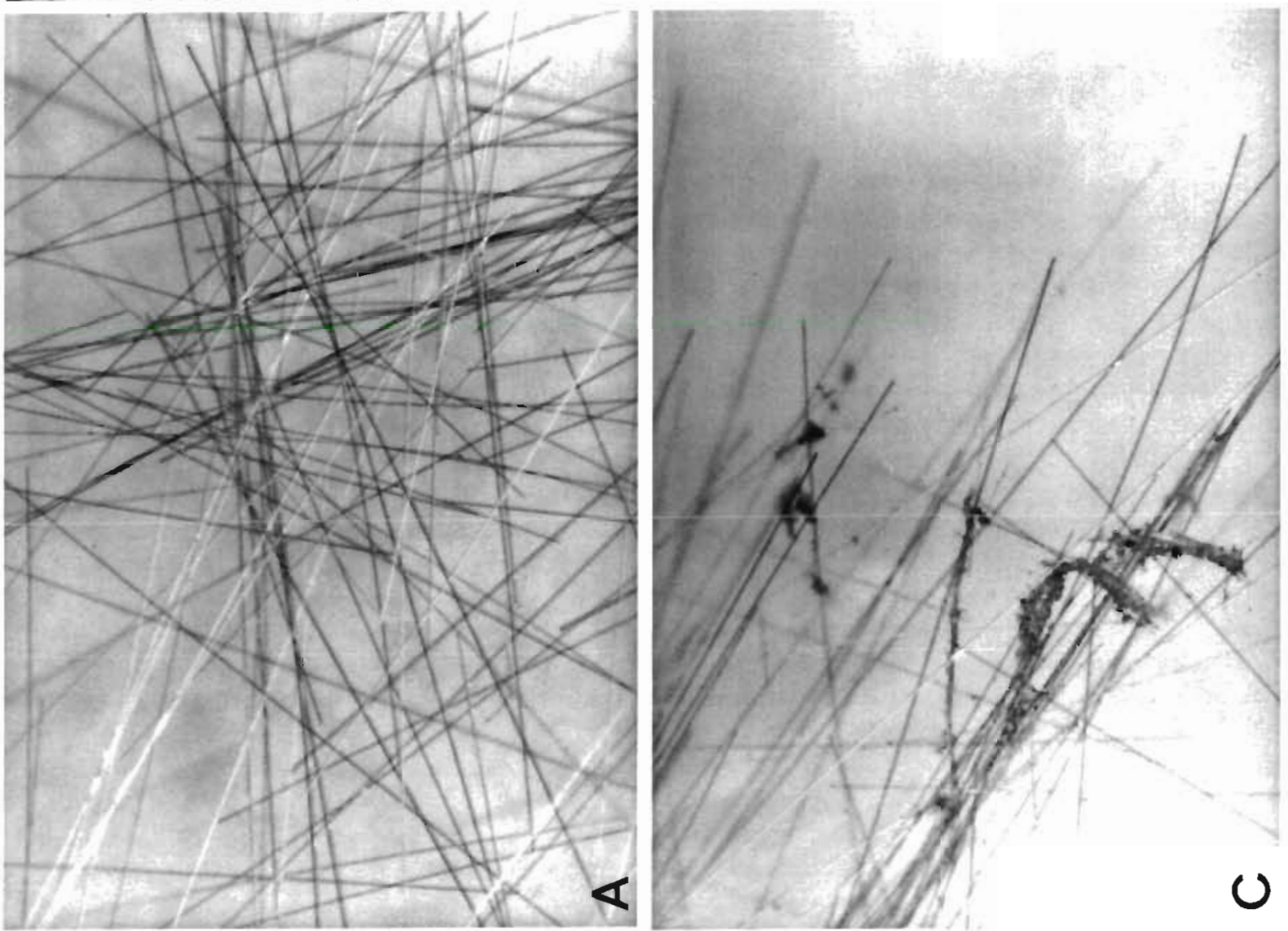
formed in treatments without $T$. nordenskjoeldii. Other diatom species (e.g. Nitzschia angularis) have also been found to form cell aggregates and non-floccing mucus (U. Passow \& A. L. Alldredge unpubl.). No flocs formed in non-rotated controls, presumably because collision rates were too low.

The amount of dissolved carbohydrates initially contributed from Thalassiosira nordenskjoeldii was in the same range as that from the mucilage of Phaeocystis. The higher initial concentration of carbohydrates in treatments with cells may have contributed to the larger decrease in dissolved carbohydrates, as the abiotic formation of particulate organic matter from dissolved, surface-active material depends on the concentration (Jensen \& Søndergaard 1982) as well as on physical processes (Johnson et al. 1986, Kepkay et al. 1990).

Two similar experiments were conducted with a natural particle assemblage and natural mucilage (which was not enriched artificially) collected with sediment traps in Balsfjord. Carbohydrates collected in traps were assumed to be mainly excretions and residuals of Phaeocystis as no other possible source was apparent. Concentrations of dissolved carbohydrates used in the experiment are in the range 10.5 to $3.5 \mathrm{mg} \mathrm{l}^{-1}$ glucose equivalents) recorded in the water during blooms of Phaeocystis. Fresh trap material consisted mostly of unidentifiable detritus with sand, debris, some fecal pellets and diatoms, but no Phaeocystis colonies were observed. Initial total (dissolved and particulate) carbohydrate concentrations for experiments varied between 0.7 and $5.9 \mathrm{mg} \mathrm{l}^{-1}$ glucose equivalents (Table 3). About 50 to $70 \%$ were dissolved carbohydrates; the rest were particulates $(>0.4 \mu \mathrm{m})$ smaller than $1000 \mu \mathrm{m}$. Large detrital mucous flocs (>1 mm) containing ubiquitous amounts of stainable polysaccharides formed within $12 \mathrm{~h}$ in all but the $100 \mathrm{~m}$ trap of the second period. The formation of large mucous flocs ( $>1 \mathrm{~mm}$ ) was reflected in the simultaneous decrease of particulate carbohydrates in the size range 0.4 to $1000 \mu \mathrm{m}$ (Table 3). Concentrations of dissolved carbohydrates decreased appreciably during flocculation of material recovered on 22 May, but not during flocculation of trap material from 27 May, when initial carbohydrate concentrations were much lower The increase in dissolved carbohydrate concentration at $100 \mathrm{~m}$ during the second period may have been caused by fragmentation and lysis of particles but may not be significant as absolute values were near the detection limit.

Concentrations of dissolved carbohydrates in the water ranged between 1 and $2 \mathrm{mg} \mathrm{l}^{-1}$ glucose equivalents during our investigation, which is lower than peak concentrations (5 $\mathrm{mg} \mathrm{l}^{-1}$ glucose equivalents) measured in the North Sea during a Phaeocystis bloom (Eberlein et al. 1985). Sedimentation rate of total carbohydrates was appreciably lower during the second sampling interval (range: 2089 to $135 \mathrm{mg} \mathrm{m}^{-2}$ $\mathrm{d}^{-1}$ glucose equivalents). The main sedimentation signal of particulate organic carbon was observed prior to our investigation (Riebesell et al. unpubl.) suggesting that an appreciable amount of carbohydrates may have sedimented in the form of mucous flocs prior to our study.

Our results suggest that during the decline of Phaeocystis blooms mucous flocs may form, consisting of mucilage accumulated during Phaeocystis blooms, which scavenge other particles, especially non-living ones. The central role of particulate polysaccharides for aggregation and the abiotic formation of polysaccharide particles from dissolved carbohydrates has been shown for other types of marine snow (Alldredge et al. 1993). Since Phaeocystis blooms produce more carbohydrates than most other planktonic communities (Fernandez et al. 1992) this process may be of special importance during blooms of Phaeocystis.

As marine snow can have high sinking rates, we hypothesize that a significant fraction of the carbon assimilated by Phaeocystis may sediment to greater

Table 3. Changes in carbohydrate concentrations (mg glucose equivalents $\mathrm{l}^{-1}$ ) during the flocculation of trap material from Balsfjord

\begin{tabular}{|c|c|c|c|c|}
\hline \multirow{2}{*}{$\begin{array}{l}\text { Deployment } \\
\text { period and } \\
\text { trap depth } \\
\text { (m) }\end{array}$} & \multicolumn{2}{|c|}{$\begin{array}{c}\text { Initial concentrations } \\
\text { (no flocs }>1 \mathrm{~mm} \text { present) }\end{array}$} & \multicolumn{2}{|c|}{$\begin{array}{c}\text { Decrease of carbohydrates } \\
\text { after flocculation }\end{array}$} \\
\hline & $\begin{array}{l}\text { Dissolved } \\
(<0.4 \mu \mathrm{m})\end{array}$ & $\begin{array}{c}\text { Particulate } \\
(0.4-1000 \mu \mathrm{m})\end{array}$ & $\begin{array}{l}\text { Dissolved } \\
(<0.4 \mu \mathrm{m})\end{array}$ & $\begin{array}{c}\text { Particulate } \\
(0.4-1000 \mu \mathrm{m})\end{array}$ \\
\hline \multicolumn{5}{|l|}{ 18-22 May } \\
\hline 40 & 2.63 & 0.84 & $60 \%$ & $43 \%$ \\
\hline 60 & 3.33 & 2.55 & $70 \%$ & $43 \%$ \\
\hline 100 & 3.44 & 2.28 & $80 \%$ & $31 \%$ \\
\hline \multicolumn{5}{|l|}{ 22-27 May } \\
\hline 40 & 1.22 & 1.31 & 0 & $60 \%$ \\
\hline 60 & 1.12 & 1.24 & 0 & $86 \%$ \\
\hline 100 & 0.47 & 0.32 & $-61 \%$ & 0 \\
\hline
\end{tabular}


depth as mucous flocs, even if cells or colonies do not sink below the euphotic zone. The concentration of dissolved carbohydrates, the amount and type of suspended particles, and the turbulence regime will influence the size of such a sedimentation signal According to this hypothesis the sedimentation rates of $\mathrm{POC}$ may be high during the decline of Phaeocystis blooms even though microscopical investigations would not reveal high sedimentation rates of Phaeocystis cells. The proposed discrepancy between flux rate of POC and phytoplankton cells may help explain the controversy on the sedimentation capacity of Phaeocystis.

Acknowledgements. The support of the workshop participants, in particular T Voji. M. Reigstad, and U. Riebesell is gratefully acknowledged. J. Egge and M. Vernet supplied valuable samples. Thanks are due to B. Gulliksen and B. Seim for excellent diving support. C. Gotschalk developed and built the underwater camera and analyzed the photographs. Comments on the manuscript by A. Alldredge, M. Vernet, U. Riebesell and L. Dilling are appreciated. The workshop was supported by the North Norwegian Coastal Ecology Programme (MARE NOR), Nordisk Kollegium for Marinbiologi and the University of Tromso. U.P. and P.W. were funded by the Deutsche Forschungsgemeinschaft (DFG) and the Norwegian Fishery Research Council (NFFR), respectively.

\section{LITERATURE CITED}

Alldredge, A., Gotschalk, C. (1989). Direct observation of the mass flocculation of diatom blooms: characteristics, settling velocity and formation of diatom aggregates Deep Sea Res. 36: 159--171

Alldredge, A. L., Passow, U., Logan, B. E. (1993). The abundance and significance of large transparent exopolymeric particles in the ocean. Deep Sea Res. 40: 1131-1140

Bodungen, B. v., Nöthig, E. M., Sui, Q. (1988). New production of phytoplankton and sedimentation during summer 1985 in the southeastern Weddell Sea. Comp. Biochem. Physiol. 90 B: $475-487$

Boekel, W. H. M. (1992). Phaeocystis colony mucus components and the importance of calcium ions for colony stability. Mar. Ecol. Prog. Ser. 87: 301-305

Boekel, W. H. M., Hansen, F C., Riegman, R., Bak, R. P. M. (1992). Lysis-mnduced decline of a Phaeocystus spring bloom and coupling with the microbial foodweb. Mar Ecol. Prog. Ser. 81, 269-276

Dubois, M., Gilles, K. A., Hamilton, J. K., Rebers, P. A., Smith, F. (1956). Colometric methods for determination of sugars and related substances. Analyt. Chem. 28: 350-356

Eberlein, K., Leal, M. T., Hammer, K. D., Hickel, W. (1985). Dissolved organic substances during a Phaeocystis pouchetii bloom in the German Bight (North Sed). Mar. Biol. 89: 311-316

Estep, K. W. Nejstgaard, J. Ch., Skjoldal, H. R., Rey, F. (1990). Predation by copepods upon natural populations of Phaeocystis pouchetii as a function of the physiological state of the prey. Mar. Ecol. Prog. Ser. 67: 235-249

Fernandez, E., Serret, P., de Madariaga, I., Harbour, D. S. Davies, A. G. (1992). Photosynthetic carbon metabolism and biochemical composition of spring phytoplankton assemblages enclosed in microcosms: the diatom - Phaeocystis sp. succession. Mar. Ecol. Prog. Ser. 90: 89-102

Guillard, R. R., Hellebust, J. H. (1971). Growth and production of extracellular substances by two strans of Phaeocystus pouchetii. J. Phycol. 7: 330-338

Hansen, B., Tande, K. S., Berggren, U. (1990). On the trophic fate of Phaeocystis pouchetii (Hariot): III. Functional grazing responses demonstrated by juvenile stages of Calanus finmarchicus (Copepoda) fed diatoms and Phaeocystis. J. Plankton Res. 12: 1173-1187

Honjo, S., Doherty, K. W., Agrawae, Y C., Asper, V L. (1984). Direct optical assessment of large amorphous aggregates (marine snow) in the deep ocean. Deep Sea Res. 31. 67-76

Huntley, M., Tande, K. S., Eilertsen, H. C. (1987). On the trophic fate of Phaeocystis pouchetii (Hariot): II. Grazing rates of Calanus hyperboreus (Krøyer) on diatoms and different size categories of $P$. pouchetii. J. exp. mar Biol Ecol. 110: 197-212

Jensen, L. V., Sendergaard, M. (1982). Abiotic formation of particles from extracellular organic carbon released by phytoplankton. Microb. Ecol. 8: 47-54

Johnson, B. D., Zhou, X. L., Wangersky, P. J (1986). Surface coagulation in sea water. Neth. J. Sea Res. 20: 201-210

Kepkay, P. E., Harrison, W. G., Irwin, B. (1990). Surface coagulation, microbial respiration, and primary production in the Sargasso Sea. Deep Sea Res. 37: 145-155

Kiorboe, T., Andersen, K. P., Dam, H. G. (1991). Coagulation efficiency and aggregate formation in marine phytoplankton. Mar. Biol. 107: 235-24.5

Kıorboe, H., Hansen, J. L. S. (1993). Phytoplankton aggregate formation: observations of patterns and mechanisms of cell sticking and the significance of exopolymeric material. J. Plankton Res. 15: 993-1018

Lancelot, C. (1983). Factors affecting phytoplankton extracellular release in the Southern Bight of the North Sea. Mar. Ecol. Prog. Ser. 12: 115-121

Lancelot, C., Billen, G., Sournia, D., Weisse, T., Colijn, F., Veldhuis, M., Davies, D., Wassmann, P. (1987). Phaeocystis blooms and nutrient enrichment in the coastal zones of the North Sea. Ambio 16: 38-40

Lancelot, C, Wassmann, P., Barth, H. (1992). Phaeocystisdominated ecosystems. Mar. Pollut. Bull. 24: 56-57

Lutter, S., Taasen, J. P., Hopkins, C. C. E., Smetacek, V. (1989). Phytoplankton dynamics and sedimentation processes during spring and summer in Balsfjord, northern Norway. Polar Biol. 10: 113-124

Riebesel., U. (1993). Aggregation of Phaeocystis during phytoplankton spring blooms in the southern North Sea. Mar Ecol. Prog. Ser. 96: 281-289

Riegmann, R., Noordeloos, A. D. M., Cadée, G. C. (1992). Phaeocystis blooms and eutrophication of the continental coastal zones of the North Sea. Mar. Biol. 112:479-484

Rousseau, V., Vaulot, D., Casotti, R., Cariou, V., Lenz, J., Gunkel, J., Baumann, M (1994). The life cycle of Phaeocystis (Prymnesiophyceae): evidence and hypotheses. In: Lancelot, C., Wassmann, P. (eds.) The ecology of Phaeocystis-dominated systems. J. mar. Syst. (in press)

Shanks, A. L., Edmondson, E. W. (1989) Laboratory-made artificial marine snow: a biological model of the real thing. Mar. Biol. 101: 463-470

Smith, W. O., Codispoti, L. A., Nelson, D. M., Manley, T., Buskey, E. J., Niebauer, H. J., Cota, G. F. (1991). Importance of Phaeocystis blooms in the high-latitude carbon cycle. Nature $35: 514-516$

Strickland, J., Parsons, T (1972), A practical handbook of seawater analysis. Bull. Fish. Res. Bd Can. 167: 1-311 
Tande, K. S., Bamstedt, U. (1987). On the trophic fate of Phaeocystis pouchetii (Hariot): I. Copepod feeding rates on solitary cells and colonies of $P$. pouchetii. Sarsia 72 : $313-320$

Thingstad, F., Billen, G. (1994). Microbial degradation of Phoeocystis material in the water. In: Lancelot, C., Wassmann, P. (eds.) The ecology of Phaeocystis-domınated systems. J. mar. Syst. (in press)

Veldhuis, M. J. W., Colijn, F., Venekamp, L. A. H. (1986). The

This article was submitted to the editor spring bloom of Phaeocystis pouchetii (Haptophyceae) in Dutch coastal waters. Neth. J. Sea Res. 20: 37-48

Wassmann, P., Vernet, M., Mitchell, B. G., Rey, F. (1990). Mass sedimentation of Phaeocystis pouchetii in the Barents Sea. Mar. Ecol. Prog. Ser. 66: 183-195

Weisse, T., Tande, K., Verity, P., Hansen, F., Gieskes, W (1994). The trophic significance of Phaeocystis blooms. In Lancelot, C., Wassmann, P. (eds.) The ecology of Phaeocystıs-dominated systems. J. mar. Syst. (in press)

Manuscript first received: Aprll 5, 1993

Revised version accepted: October 19, 1993 